\title{
Specialized edaphic niches of threatened copper endemic plant species in the D.R. Congo: implications for ex situ conservation
}

\author{
Sylvain Boisson • Michel-Pierre Faucon • Soizig Le Stradic • Bastien Lange • \\ Nathalie Verbruggen • Olivier Garin • Axel Tshomba Wetshy • Maxime Séleck • \\ Wilfried Masengo Kalengo • Mylor Ngoy Shutcha • Grégory Mahy
}

Received: 16 June 2016 / Accepted: 19 October 2016

(C) Springer International Publishing Switzerland 2016

\begin{abstract}
Background and aims Copper $(\mathrm{Cu})$ rich soils derived from rocks of the Katangan Copperbelt in the southeastern Democratic Republic of Congo (DRC) support a rich diversity of metallophytes including 550 heavy metal tolerant; 24 broad $\mathrm{Cu}$ soil endemic; and 33 strict
\end{abstract}

Responsible Editor: Antony Van der Ent.

S. Boisson $(\bowtie) \cdot$ S. Le Stradic • O. Garin • M. Séleck • G. Mahy

Biodiversity and Landscape Unit, BIOSE - Biosystem Engineering Department, Gembloux Agro-Bio Tech, University of Liege, 2 Passage des Déportés, 5030 Gembloux, Belgium e-mail: sylvain.boisson@ulg.ac.be

\section{M.-P. Faucon · B. Lange}

Hydrogeochimical Interactions Soil-Environment (HydrISE) Unit, Polytechnic Institute LaSalle Beauvais (ISAB-IGAL), 15 rue

Pierre Waguet, 60026 Beauvais, France

B. Lange

Laboratory of Plant Ecology and Biogeochemistry, Université Libre Bruxelles, CP 244, Boulevard du Triomphe, 1050 Bruxelles, Belgium

\section{N. Verbruggen}

Laboratory of Plant Physiology and Molecular Genetics, Université Libre de Bruxelles, CP 244, Boulevard du Triomphe, 1050 Bruxelles, Belgium

A. Tshomba Wetshy · W. Masengo Kalengo •

M. Ngoy Shutcha

Ecology, Restoration Ecology and Landscape Research Unit,

Faculty of Agronomy, University of Lubumbashi,

Route Kasapa, Campus Universitaire, 1825 Lubumbashi,

Democratic Republic of Congo
$\mathrm{Cu}$ soil endemic plant species. The majority of the plant species occur on prominent $\mathrm{Cu}$ hills scattered along the copperbelt. Heavy metal mining on the Katangan Copperbelt has resulted in extensive degradation and destruction of the $\mathrm{Cu}$ hill ecosystems. As a result, approximately $80 \%$ of the strict $\mathrm{Cu}$ endemic plant species are classified as threatened according to IUCN criteria and represent a conservation priority. Little is known about the soil $\mathrm{Cu}$ tolerance optimum of the $\mathrm{Cu}$ endemic plant species. The purpose of this study was to quantify the soil $\mathrm{Cu}$ concentration ( $\mathrm{Cu}$ edaphic niche) of four $\mathrm{Cu}$ endemic plant species to inform soil propagation conditions and microhabitat site selection for planting of the species in $\mathrm{Cu}$ hill ecosystem restoration.

Methods The soil $\mathrm{Cu}$ concentration tolerance of $\mathrm{Cu}$ endemic plant species was studied including Crotalaria cobalticola (CRCO); Gladiolus ledoctei (GLLE); Diplolophium marthozianum (DIMA); and Triumfetta welwitschii var. rogersii (TRWE-RO). The in situ natural habitat distributions of the $\mathrm{Cu}$ endemic plant species with respect to soil $\mathrm{Cu}$ concentration ( $\mathrm{Cu}$ edaphic niche) was calculated by means of a generalised additive model. Additionally, the seedling emergence and growth of the four $\mathrm{Cu}$ endemic plant species in three soil $\mathrm{Cu}$ concentrations was tested ex situ and the results were compared to that of the natural habitat soil $\mathrm{Cu}$ concentration optimum (Cu edaphic niche).

Results CRCO exhibited greater performance on the highest soil $\mathrm{Cu}$ concentration, consistent with its calculated $\mathrm{Cu}$ edaphic niche occurring at the highest soil $\mathrm{Cu}$ concentrations. In contrast, both DIMA and TRWE-RO exhibited greatest performance at the lowest soil $\mathrm{Cu}$ 
concentration, despite the calculated $\mathrm{Cu}$ edaphic niche occurring at moderate soil $\mathrm{Cu}$ concentrations. GLLE exhibited equal performances in the entire range of soil $\mathrm{Cu}$ concentrations.

Conclusions These results suggest that CRCO evolved via the edaphic specialization model where it is most competitive in $\mathrm{Cu}$ hill habitat with the highest soil $\mathrm{Cu}$ concentration. In comparison, DIMA and TRWE-RO appear to have evolved via the endemism refuge model, which indicates that the species were excluded into (i.e., took refuge in) the lower plant competition $\mathrm{Cu}$ hill habitat due to their inability to effectively compete with higher plant competition on normal soils. The soil $\mathrm{Cu}$ edaphic niche determined for the four species will be useful in conservation activities including informing soil propagation conditions and microhabitat site selection for planting of the species in $\mathrm{Cu}$ hill ecosystem restoration.

Keywords Copper soil · Heavy metal tolerance . Edaphic Endemic $\cdot$ Niche $\cdot$ Generalised additive model . Endangered plant

\section{Introduction}

Metalliferous substrates including natural soils derived from metal-rich rocks and minerals, as well as anthropogenic mine tailings, present a chemically extreme environment for plant establishment and productivity (Shaw 1990; Brooks 1998). Due to the microbially-mediated oxidation of associated metal sulfides, the substrate $\mathrm{pH}$ is typically low $(<5)$ and the resulting bioavailable heavy metal availability is high. Metalliferous substrates (eg., mining complexes) are an uncommon and unusual habitat type that may be widely distributed and have an island-like distribution, subject to the selective processes that occur with respect to island biogeography (Kruckeberg 1986). Evolution of tolerance to the chemically extreme conditions of the metalliferous substrates, in combination with the isolating effects of island-like distribution of the habitat, promotes speciation and can be the origin of edaphic endemic plant species (Antonovics et al. 1971; Kruckeberg and Rabinowitz 1985; Kruckeberg 1986; Baker 1987; Kruckeberg and Kruckeberg 1990; Shaw 1990; Brooks 1998; Macnair and Gardner 1998; Van Rossum et al. 2004; Rajakaruna and Boyd 2008; Harrison and Rajakaruna 2011; Escarré et al. 2013).
The origins of edaphic endemic plant species can be determined by genetic analysis of biotic depletion, allopatric speciation or genetic differentiation of individuals occurring in populations (Kruckeberg and Rabinowitz 1985; Macnair and Gardner 1998; Rajakaruna 2004) and/or through ecological comparison (Gankin and Major 1964; Meyer 1986; Harrison and Rajakaruna 2011). There are three leading models regarding the origin of edaphic endemic plant species including 1) endemism refuge, 2) edaphic specialization, and 3) pathogen refuge (Gankin and Major 1964; Meyer 1986; Boyd 2007; Springer 2009; Fones et al. 2010; Peng et al. 2012; Faucon et al. 2012a; Boyd and Rajakaruna 2013; Anacker 2014). In the endemism refuge model, edaphic stress tolerant plant species are outcompeted on normal soils and displaced into (or take refuge in) metalliferous soil habitats where competitive pressure is lower (Gankin and Major 1964; Anacker 2014). In the edaphic specialization model, a plant species becomes specialized to metalliferous soil habitats because they outcompete other plant species in those habitats and/or have a high physiological requirement for the metal (Gankin and Major 1964; Boyd and Rajakaruna 2013; Anacker 2014). In the pathogen refuge model, the high bioavailability of heavy metal reduces pathogens (eg., pathogenic fungi) that typically adversely impact the plant species (Boyd 2007; Springer 2009; Fones et al. 2010; Strauss and Boyd 2011).

Copper $(\mathrm{Cu})$ rich soils derived from rocks of the Katangan Copperbelt in the south-eastern D. R. Congo support a rich diversity of metallophytes including 550 heavy metal tolerant; 24 broad $\mathrm{Cu}$ soil endemic; and 33 strict $\mathrm{Cu}$ soil endemic plant species (Malaisse et al. 1999); Duvigneaud and Denaeyer-De Smet 1963; Cailteux et al. 2005). Soils on the hills of the Katangan Copperbelt present large differences in soil $\mathrm{Cu}$ concentration that varies by topographic position (Duvigneaud and Denaeyer-De Smet 1963; Cailteux et al. 2005). On the hill tops, plant-available soil $\mathrm{Cu}$ concentration ranges from 3500 to $10,000 \mathrm{mg} \mathrm{kg}^{-1}$ and declines to $100-3500 \mathrm{mg} \mathrm{kg}^{-1}$ on hillslopes and toeslopes (Duvigneaud and Denaeyer-De Smet 1963; Ilunga wa Ilunga et al. 2013; Séleck et al. 2013). Plant species endemic to the $\mathrm{Cu}$ hills exhibit niche segregation with some species occurring primarily on hill tops at the higher soil $\mathrm{Cu}$ concentration and other species occurring on hillslopes and toeslopes at the lower soil $\mathrm{Cu}$ concentration. Heterogeneity of heavy metal concentrations 
within and among sites could lead to divergent selection in the population and thus contribute to ecotypic differentiation (Ilunga wa Ilunga et al. 2013). Studies on some of these $\mathrm{Cu}$ endemic plant species have identified a high degree of intraspecific variability with respect to heavy metal tolerance differences (Faucon et al. 2012a) and genetic structure among populations (Peng et al. 2012; Faucon et al. 2012a).

The recent revival of $\mathrm{Cu}$ and $\mathrm{Co}$ mining on the Katangan Copperbelt has led to the destruction and degradation of the unique and rare $\mathrm{Cu}$ hill ecosystems (Brooks and Malaisse 1990; Leteinturier et al. 1999; Saad et al. 2012). To date, approximately $80 \%$ of $\mathrm{Cu}$ endemic plant species have been identified as threatened (i.e., critically endangered, endangered or vulnerable) according to IUCN criteria (Faucon et al. 2010), and represent a conservation priority. Although establishing preserves where mining is banned would be the most effective strategy to protect the $\mathrm{Cu}$ hill ecosystems (Leteinturier 2002; Saad et al. 2012), this appears unrealistic since $\mathrm{Cu}$ and Co mining comprises a large percentage of $\mathrm{D}$. R. Congo's economic base. The lack of recognition of the $\mathrm{Cu}$ endemic plant species in environmental protection laws and regulations in the D. R. Congo further hampers conservation of the $\mathrm{Cu}$ hill ecosystems.

In addition to in situ species conservation, ex situ strategies such as the establishment of a $\mathrm{Cu}$ endemic plant species seed bank, plant propagation, and revegetation of lands degraded by mining is important in maintaining biological integrity of the $\mathrm{Cu}$ hill ecosystems (Faucon et al. 2011; Faucon et al. 2012b; Saad et al. 2012; Faucon et al. 2016). Greater knowledge of the ecology of a plant species including the abiotic (e.g., soil $\mathrm{Cu}$ concentration) and biotic factors that influence species distribution can improve propagation techniques and ecosystem restoration success. To date, most studies focusing on $\mathrm{Cu}$ endemic plant species of the Katangan Copperbelt have been performed under laboratory conditions that poorly match the natural conditions of $\mathrm{Cu}$ hill ecosystems (Chipeng et al. 2010; Faucon et al. 2012a; Godefroid et al. 2013; Boisson et al. 2016a; Boisson et al. 2016c). In this context, the purpose of this study was to determine the in situ natural $\mathrm{Cu}$ edaphic niche and ex situ growth response to a gradient of soil $\mathrm{Cu}$ concentration for the $\mathrm{Cu}$ endemic plant species Crotalaria cobalticola, Diplolophium marthozianum, Gladiolus ledoctei and Triumfetta welwitschii var. rogersii.

\section{Methods}

Study site

The study was performed at sites between the towns of Tenke (Lat. -10.603889, Lon. 26.121343 and Fungurume (Lat. -10.617539, Lon. 26.309615 in the far south-eastern D. R. Congo in the Katangan Copperbelt. In the Katangan Copperbelt, scattered $\mathrm{Cu}$ hills were formed during the weathering of the most resistant siliceous rock of the Roan Series (Duvigneaud and Denaeyer-De Smet 1963, François 1973, Cailteux et al. 2005). Altitude of the area ranges from 1200 to $1400 \mathrm{~m}$. This region has a humid subtropical climate (Cwa; Köppen climate) with warm, rainy summers (November to March) and pleasant, dry winters (May to September). Autumn (April) and spring (October) are transition periods between the two seasons.

The dominant vegetation types is Miombo (Brachystegia) woodland and savannah. Two major plant communities have been identified along the $\mathrm{Cu}$ hill topographic gradient, including steppe (grassland) on the hill tops, gradating into savannah on the hillslopes and the toeslopes (Séleck et al. 2013). Soils on hill tops contains bioavailable $\mathrm{Cu}$ concentrations ranging from $3500 \mathrm{mg} \mathrm{kg}^{-1}$ to $10,000 \mathrm{mg} \mathrm{kg}^{-1}$, whereas soil plant-available $\mathrm{Cu}$ concentration is substantially lower on hillslopes and toeslopes, with lows of $100 \mathrm{mg} \mathrm{kg}^{-1}$ (Duvigneaud and Denaeyer-De Smet 1963; Ilunga wa Ilunga et al. 2013; Séleck et al. 2013).

\section{Study plant species}

Our study focused on four plant species endemic to the Katanga Copperbelt, including Crotalaria cobalticola P.A. Duvign. \& Plancke (CRCO; Fabaceae); Diplolophium marthozianum P.A. Duvign. (DIMA; Apiaceae); Gladiolus ledoctei P.A. Duvign. \& Van Bockstal (GLLE; Iridaceae); and Triumfetta welwitschii var. rogersii (N.E. Br.) Brummitt \& Seyani (TRWE-RO; Malvaceae). $\mathrm{CRCO}$ is a strict $\mathrm{Cu}$ endemic herbaceous annual. It is primary distributed in the steppe (grassland) on $\mathrm{Cu}$ hills. Both DIMA and GLLE are broad $\mathrm{Cu}$ endemic herbaceous perennials. Both species occur in savannah on $\mathrm{Cu}$ hills, but GLLE is more common in the steppe. TRWE-RO is a strict $\mathrm{Cu}$ endemic herbaceous perennial. It is primarily present in savannah on $\mathrm{Cu}$ hills. CRCO, DIMA, and GLLE are all proposed endangered 
(EN) IUCN status (Faucon et al. 2010). TRWE-RO has no proposed IUCN status due to taxonomic data deficiency (DD).

In situ modelling of plant species $\mathrm{Cu}$ edaphic niches

The in situ $\mathrm{Cu}$ edaphic niches of the plant species CRCO, DIMA, GLLE, and TRWE-RO were modelled using the species presence-absence database from Séleck et al. (2013). This database contains phytosociological data of 172 square-metre plots surveyed along systematic grids on three $\mathrm{Cu}$ hills between the towns of Tenke and Fungurume. Data from each vegetation plot was linked with bioavailable (EDTA-extractable) soil Cu concentration in soil from the database of Séleck et al. (2013). Edaphic niches along the natural $\mathrm{Cu}$ gradient for each plant species were then modelled with generalised additive models (GAM), using a binomial likelihood (Hastie and Tibshirani 1986). The resulting species response curves represent the probability of occurrence of the taxon along the $\mathrm{Cu}$ gradient. For each taxon, the best fit model among three degrees of smoothing (3, 4 or 5) was selected, based on the Aikaike Information Criterion (AIC; Aikaike 1987). The optimum soil $\mathrm{Cu}$ concentration of each taxa was then estimated by identifying the highest probability of occurrence. The borders of the $\mathrm{Cu}$ edaphic niche widths (or amplitudes) were determined by the lower and upper limits of $80 \%$ of the area under the species response curves (Gégout and Pierrat 1998) followed by the calculation of the $\mathrm{Cu}$ edaphic niche widths as the difference between the upper and the lower limits.

Plant species response to $\mathrm{Cu}$ in ex situ conditions

\section{Seed collection}

Seeds of CRCO, DIMA, GLLE, and TRWE-RO were collected from $\mathrm{Cu}$ hills located between Tenke and Fungurume (Table 1). For each species, seeds were collected on a minimum of 50 individuals from distinct populations from three separate hill tops (three populations). Seed samples were stored in ultra-dry (relative humidity $<5 \%$ ) conditions at room temperature.

\section{Soil treatment preparation and analyses}

Three soil $\mathrm{Cu}$ level treatments were created using a homogeneous arable soil (ferralsol; oxisol) as the base substrate and additions of $\mathrm{Cu}$ in the form of copper sulfate pentahydrate $\left(\mathrm{CuSO}_{4} .5 \mathrm{H}_{2} \mathrm{O}\right)$ powder. The base ferralsol soil has a very low natural bioavailable $\mathrm{Cu}$ concentration (27.2 $\mathrm{mg} \mathrm{kg}^{-1}$; see Results). Additionally, bioavailable macronutrient content is

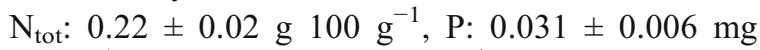
$100 \mathrm{~g}^{-1}, \mathrm{~K}: 56.0 \pm 2.4 \mathrm{mg} 100 \mathrm{~g}^{-1}$, Ca: $92.0 \pm 5.9 \mathrm{mg}$

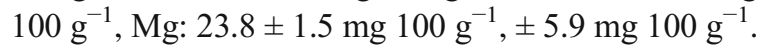
Soil texture of this soil has been identified as sandy-clay (Mukalay et al. 2008). Total nitrogen (N) content was measured by combustion of organic matter to $\mathrm{NO}_{\mathrm{x}}$ and $\mathrm{N}_{2}$ at $1050{ }^{\circ} \mathrm{C}$ in a flow of oxygen and measured by Thermal Conductivity Detection (Margesin and Schinner 2005). Phosphorus (P) content was determined with a Shimadzu UV-1205 spectrophotometer (Shimadzu Corporation) at $430 \mathrm{~nm}$ after the development of blue coloration. Bioavailable soil $\mathrm{Ca}, \mathrm{Cu}, \mathrm{Mg}, \mathrm{K}$ concentration were analysed by ammonium acetateEDTA $\left(\mathrm{CH}_{3} \mathrm{COONH}_{4}-\right.$ EDTA $) 0.5 \mathrm{~N}$ extraction (Lakanen and Erviö 1971). The soil:solution ratio was $1: 5$ and the $\mathrm{pH}$ of the extraction solution was buffered at 4.65. The supernatant was filtered through a S\&S 595 folded filter and analysed using a flame atomic absorption spectrometer (Varian 220), following the norm NF X 31-120.

For the control (low $\mathrm{Cu}$ "treatment"), no $\mathrm{Cu}$ was added. For the medium $\mathrm{Cu}$ treatment, $100 \mathrm{mg} \mathrm{kg}^{-1}$ soil $\mathrm{Cu}$ was added and thoroughly mixed (theoretical total $127.2 \mathrm{mg} \mathrm{kg}^{-1} \mathrm{Cu}$ ). For the high $\mathrm{Cu}$ treatment, $1000 \mathrm{mg} \mathrm{kg}^{-1}$ soil of $\mathrm{Cu}$ was added and thoroughly mixed (theoretical total $1027.2 \mathrm{mg} \mathrm{kg}^{-1} \mathrm{Cu}$ ).

\section{Study establishment}

This study was conducted outdoors at ambient climate conditions in the experimental botanical garden of the University of Lubumbashi (Faculty of Agronomy; Lat. -11.610005 , Lon. 27.480011), $180 \mathrm{~km}$ southeast of Tenke and Fungurume. Climatic conditions of the experimental garden closely match that of the plant populations original sites.

Plastic nursery bags were filled with $1.5 \mathrm{~kg}$ (c. $20 \mathrm{~cm}$ height) of the different substrates for $n=10$ of each soil $\mathrm{Cu}$ treatment per plant species. Bags were perforated to facilitate water drainage. For each combination of species and population, five seeds were sown per bag in early December, at the beginning of the rainy season. The bags were then fully randomized and placed under a shade structure and watered to field capacity to initiate seed germination. During the study, all bags were 
Table 1 Plant species seed collected at each site.

\begin{tabular}{|c|c|c|c|c|c|c|c|}
\hline \multirow[t]{2}{*}{ Site name } & \multirow[t]{2}{*}{ Site ID } & \multirow[t]{2}{*}{ Latitude } & \multirow[t]{2}{*}{ Longitude } & \multicolumn{4}{|c|}{ Plant species collected } \\
\hline & & & & CRCO & GLLE & DIMA & TRWE-RO \\
\hline Fungurume V & A & -10.618049 & 26.290399 & $\mathrm{X}$ & $\mathrm{X}$ & $\mathrm{X}$ & \\
\hline Fungurume VIII [1] & A & -10.601051 & 26.311085 & & & & $\mathrm{X}$ \\
\hline Kakalawe [1] & $\mathrm{B}$ & -10.613342 & 26.133768 & & & $\mathrm{X}$ & \\
\hline Shimbidi & $\mathrm{B}$ & -10.592873 & 26.142197 & & $\mathrm{X}$ & & \\
\hline Kabwelunono [1] & $\mathrm{B}$ & -10.596726 & 26.133318 & $\mathrm{X}$ & & & $\mathrm{X}$ \\
\hline Kavifwafwaulu [1] & $\mathrm{C}$ & -10.579099 & 26.153847 & & $\mathrm{X}$ & & \\
\hline Kavifwafwaulu [4] & $\mathrm{C}$ & -10.582313 & 26.152612 & $\mathrm{X}$ & & $\mathrm{X}$ & $\mathrm{X}$ \\
\hline
\end{tabular}

watered to field capacity every two days and fully rerandomized every two days.

Seedling emergence for each bag was recorded weekly. After all of the seedlings had established after two months in January, the number of seedlings per bag was reduced to a single individual and allowed to grow for another five months until termination of the study at the end of April. At termination of the study, the maximum height of each plant was measured. Additionally, for CRCO only, the number of main stems, the total number of flowers, and the maximum root length was measured. For DIMA and TRWE-RO only, the number of leaves was counted.

\section{Post-plant growth soil analyses}

At termination of the study, soils were randomly collected from 12 bags representing each plant species $\times$ soil $\mathrm{Cu}$ treatment, in order to have four replicates of soil treatment. Soil samples were air dried and sieved to $2 \mathrm{~mm}$ prior to the analyses. Soil $\mathrm{pH}$ was measured in potassium chloride (KCl) $1 \mathrm{~N}$ with a glass electrode in a 2:5 soil:solution ratio, after a $2 \mathrm{~h}$ equilibration time. Bioavailable soil $\mathrm{Cu}$ concentration was measured using the flame atomic absorption spectrometer on the supernatant, following the norm NF X 31-120, as detailed previously.

\section{Data analysis}

The percentage of seedling emergence per bag was compared using a two-way ANOVA (plant population $\times$ soil $\mathrm{Cu}$ concentration; $\mathrm{R}$ statistical software). The growth parameters (i.e., height, number of leaves or main stems and length of the root system) and the number of flowers per individual were also compared by a two-way ANOVA (population $\times$ soil $\mathrm{Cu}$ concentration). Prior to analysis, normality and homoscedasticity of the data were checked. Log transformations were required for the number of flowers of CRCO and number of leaves for TRWE-RO. Means were structured via the Tukey HSD test, with an error rate of $5 \%$. Soil compounds were compared with a Kruskal-Wallis test followed by a Bonferroni mean adjustment comparison. Spearman correlation tests were performed between height and number of leaves (or stems), to identify the relationship between these responses. All analyses were performed using the $\mathrm{R}$ statistical software ( $\mathrm{R}$ Development Core Team 2010).

\section{Results}

Soil $\mathrm{Cu}$ concentration

As expected, soil analyses revealed that the EDTAextractable $\mathrm{Cu}$ concentrations were significantly higher in the $1000 \mathrm{mg} \mathrm{kg}^{-1} \mathrm{Cu}$-enriched soils than the two other soils (control and $100 \mathrm{mg} \mathrm{kg}^{-1} \mathrm{Cu}$-enriched soils), $\left(X^{2}=8.346 ; p\right.$-value $<0.05$; Table 2$)$. The $\mathrm{pH}$ values were inversely proportional to the $\mathrm{Cu}$ concentrations added in soils with a significantly lower $\mathrm{pH}$ in $1000 \mathrm{mg} \mathrm{kg}^{-1} \mathrm{Cu}$-enriched soils than in the control and the $100 \mathrm{mg} \mathrm{kg}^{-1}\left(X^{2}=7.731 ; p\right.$-value $<0.05$, Table 2). The means stayed between $5.0 \pm 0.3$.

Plant species response to soil $\mathrm{Cu}$ concentration

\section{Seedling emergence}

Global means of the percentages of emergence differed according to the species. GLLE and CRCO presented 
Table 2 Physico-chemical conditions (Mean $\pm \mathrm{SD})$ including the EDTA-extractable copper $(\mathrm{Cu})$ of the three substrates of the test $(n=4)$

\begin{tabular}{llllll}
\hline Physico-chemical parameters & \multicolumn{2}{l}{ Soil Cu treatment $\left(\mathrm{mg} \mathrm{kg}^{-1}\right)$} & & \multicolumn{2}{c}{ Kruskal-Wallis test } \\
\cline { 2 - 5 } & Control (0) & 100 & 1000 & $X^{2}$ & $p$-value \\
\hline $\mathrm{Cu}\left(\mathrm{mg} \mathrm{kg}^{-1}\right)$ & $96.7 \pm 12.4^{\mathrm{b}}$ & $128.1 \pm 38.1^{\mathrm{b}}$ & $1280.9 \pm 322.4^{\mathrm{a}}$ & 8.346 & 0.015 \\
$\mathrm{pH} \mathrm{KCl}$ & $5.2 \pm 0.1^{\mathrm{b}}$ & $5.1 \pm 0.1^{\mathrm{b}}$ & $4.7 \pm 0.0^{\mathrm{a}}$ & 7.731 & 0.021 \\
\hline
\end{tabular}

the highest percentage of emergence, respectively $49.6 \pm 3.0 \%$ and $44.4 \pm 4.8 \%$ (Mean $\pm \mathrm{SE}$ ), in comparison to TRWE-RO and DIMA, which had percentages of emergence of $13.1 \pm 2.1 \%$ and $11.7 \pm 1.5 \%$, respectively. Our results suggest that the percentage of emergence of the four plant species was not affected by $\mathrm{Cu}$ concentration (Table 3 ). In contrast, the percentage of emergence for the population of TRWE-RO from Fungurume VIII $(24.7 \pm 4.5 \%)$ was significantly higher than the populations from Kavifwafwaulu [4] $(10.7 \pm 3.4 \%)$ and Kabwelunono [1] $(4.0 \pm 1.8 \%$, $F=9.323, p$-value $<0.001)$. For CRCO and TRWE$\mathrm{RO}$, no interaction between the population and $\mathrm{Cu}$ concentrations were identified for the percentages of emergence (CRCO: $F=0.334$; $p$-value $=0.855$; TRWE-RO: $F=0.608, p$-value $=0.657$ ). Interactions between both factors affected the percentages of emergence for GLLE $(F=3.665, p$-value $<0.01)$ and DIMA $(F=2.500, p$ value $=0.049$ ), but no significant difference between the combination of the population and the $\mathrm{Cu}$ concentrations were evident in the Tukey HSD test.

\section{Plant species growth response}

There was no significant interaction between the different populations within a species and the soil $\mathrm{Cu}$ concentration on the growth for the four plant species. Effects of each factor are thus highlighted independently. Considering that the individual plant height and the number of main stems of individuals of CRCO were correlated and presented the same pattern of variation (Spearman coefficient correlation $=0.80, p$-value $<0.001$ ), only the number of stems is presented in the results. The number of main stems was not significantly different between the populations within a species, but was significantly different between soil $\mathrm{Cu}$ concentrations. Individuals grown on control soils had significantly fewer stems $(9.8 \pm 2.1$ stems $)$ than the $100 \mathrm{mg} \mathrm{kg}^{-1}$ $(17.8 \pm 1.8$ stems $)$ and the $1000 \mathrm{mg} \mathrm{kg}^{-1} \mathrm{Cu}$ treatment soils (21.5 \pm 2.0 stems; Fig. 1; Table 3$)$. The same pattern of response to soil $\mathrm{Cu}$ concentration was also observed for the length of the root system, with significantly longer roots observed in individuals growing on $1000 \mathrm{mg} \mathrm{kg}^{-1}(5.5 \pm 0.6 \mathrm{~cm})$ and on $100 \mathrm{mg} \mathrm{kg}^{-1} \mathrm{Cu}$ treatment soils $(5.3 \pm 0.8 \mathrm{~cm})$, than on the control soils $(2.6 \pm 0.7 \mathrm{~cm}$; Table 3$)$. While the number of flowers per individual did not significantly vary between soil $\mathrm{Cu}$ concentrations (Table 3), the percentage of flowering individuals was higher on those on the 100 and $1000 \mathrm{mg} \mathrm{kg}^{-1} \mathrm{Cu}$ treatment soils (respectively $36 \%$ and $44 \%$ ) than on the control soils ( $25 \%)$.

The individuals of DIMA presented a distinctly different pattern in relation to $\mathrm{Cu}$ concentrations (Fig. 1; Table 3). Considering that the number of leaves was significantly correlated with the height $(r=0.73, p$-value $<0.001)$, the number of leaves was chosen for the comparisons. The number of individuals' leaves was greater on the control soils $(4.6 \pm 0.6$ leaves $)$ and in the $100 \mathrm{mg} \mathrm{kg}^{-1} \mathrm{Cu}$ treatment soils (4.9 \pm 0.6 leaves), than on the $1000 \mathrm{mg} \mathrm{kg}^{-1} \mathrm{Cu}$ treatment soils $(2.8 \pm 0.4$ leaves, Fig. 1; Table 3). Additionally, an effect of population was observed, in which the number of leaves of individuals from the Kakalalwe [1] population ( $4.9 \pm 0.5$ leaves) was significantly higher than the mean number of leaves of individuals from the Fungurume $\mathrm{V}$ $(2.9 \pm 0.3$ leaves $)$ and Kavifwafwaulu [4] $(3.3 \pm 0.3$ leaves, Table 3) populations. For GLLE the height of individuals and the number of the individuals' leaves were not significantly different, either between populations (Table 3) or soil $\mathrm{Cu}$ concentrations (Fig. 1; Table 3).

Since a significant positive correlation was observed between the number of leaves and the height of TRWERO ( $r=0.56, p$-value $<0.001)$, only the results for the number of leaves according to the soil $\mathrm{Cu}$ concentrations were presented. The number of leaves for plants that were grown on the control soils $(16.3 \pm 1.6$ leaves $)$ and on $100 \mathrm{mg} \mathrm{kg}^{-1} \mathrm{Cu}$ treatment soils $(15.1 \pm 1.6$ 


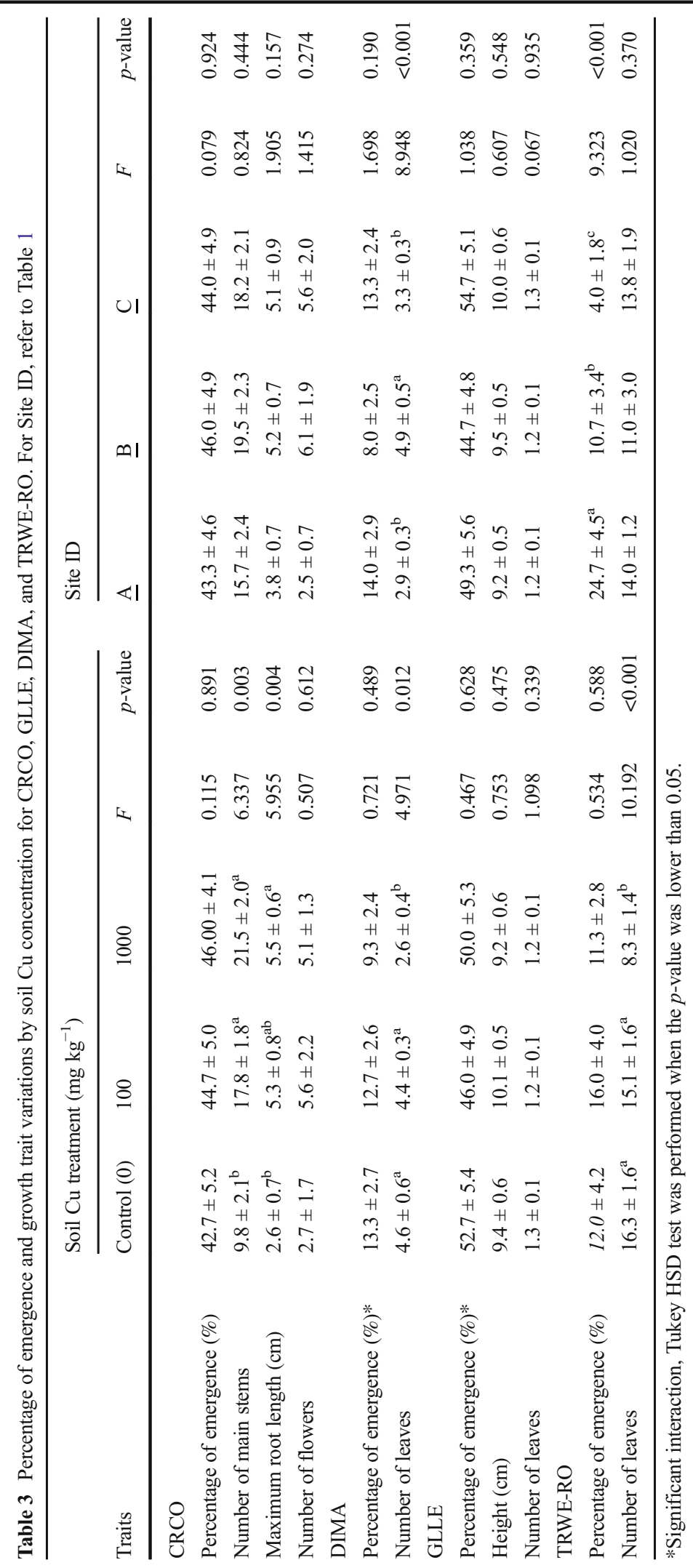


Fig. 1 Growth response (number of stems or number of leaves; mean $\pm \mathrm{SE}$ ) of CRCO, DIMA, GLLE and TRWE-RO to soil $\mathrm{Cu}$ concentration (ex situ; $\mathrm{mg} \mathrm{kg}^{-1}$; vertical bar graphs) as compared to soil $\mathrm{Cu}$ concentration from natural populations (in situ; $\mathrm{mg}$ $\mathrm{kg}^{-1}$; slider bar graphs). Means with the same letters are not significantly different, according to the Tukey HSD test. Natural soil $\mathrm{Cu}$ concentrations $(\mathrm{Cu}$ edaphic niches) of the species were modelled by generalised additive models (GAM). Dots are the niche optima of taxa determined by the gradient value of the highest probability of occurrence. Thick and straight lines are the niche widths (or amplitudes) calculated by the difference between the borders of area of $80 \%$ under the species response curves
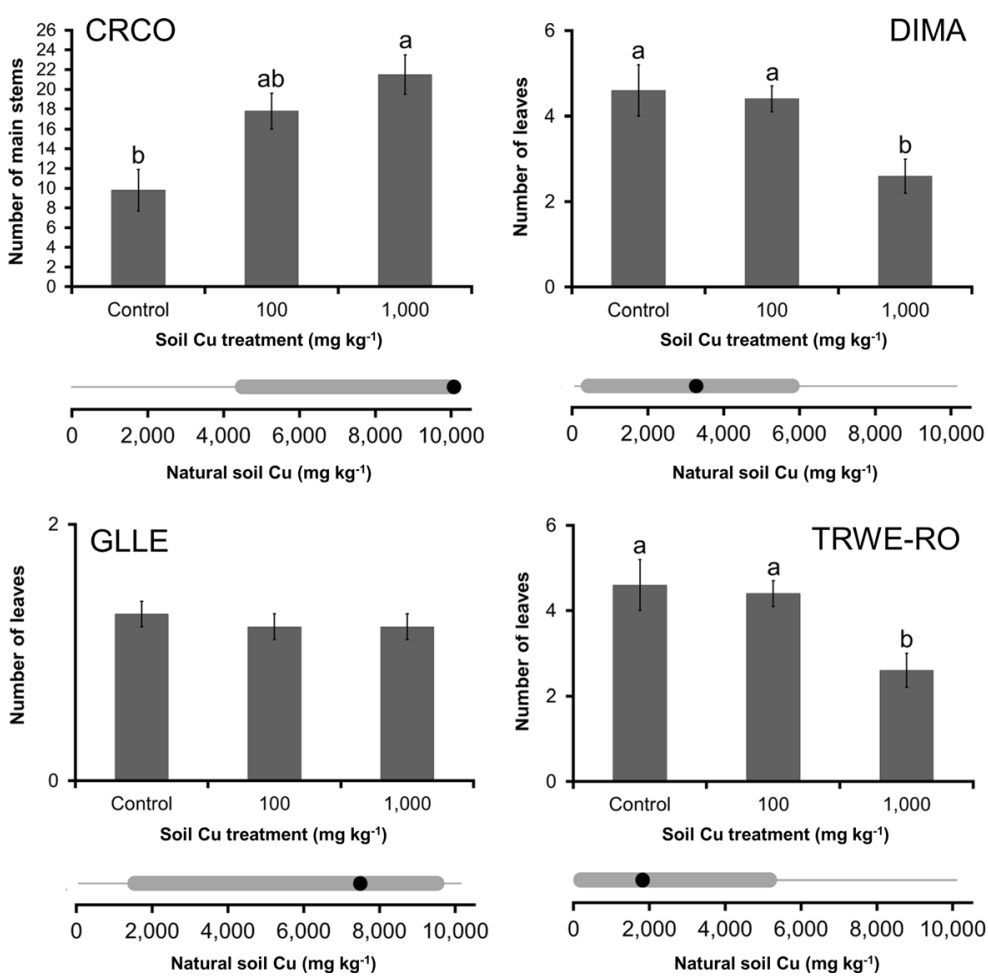

leaves) were significantly greater than the number of leaves for plants sown on $1000 \mathrm{mg} \mathrm{kg}^{-1} \mathrm{Cu}$ treatment soils $(8.3 \pm 1.4$ leaves, Fig. 1 ; Table 3$)$. Population of origin did not affect the number of leaves (Table 3 ).

\section{In situ Cu edaphic niches of plant species}

The four plant species have distinct, however overlapping, in situ $\mathrm{Cu}$ edaphic niches (Fig. 1). CRCO's optimum soil $\mathrm{Cu}$ concentration was $10,136 \mathrm{mg} \mathrm{kg}^{-1} \mathrm{Cu}$, with a truncated response curve, and a lower limit of its $\mathrm{Cu}$ edaphic niche, at $4547 \mathrm{mg} \mathrm{kg}^{-1} \mathrm{Cu}$ (Fig. 1). CRCO could be considered the most $\mathrm{Cu}$ tolerant of our study. GLLE occurred in a range of 1525 to $9499 \mathrm{mg} \mathrm{kg}^{-1} \mathrm{Cu}$, with a $\mathrm{Cu}$ optimum at $7468 \mathrm{mg} \mathrm{kg}^{-1} \mathrm{Cu}$ (Fig. 1). Its response curve was skewed, with a longer tail toward the lowest soil $\mathrm{Cu}$ concentrations. DIMA's optimum soil $\mathrm{Cu}$ concentration was $3243 \mathrm{mg} \mathrm{kg}^{-1} \mathrm{Cu}$, with a symmetrical niche width (5387 $\mathrm{mg} \mathrm{kg}^{-1} \mathrm{Cu}$, Fig. 1). TRWERO's $\mathrm{Cu}$ edaphic niche optimum was at a soil $\mathrm{Cu}$ concentration of $1838 \mathrm{mg} \mathrm{kg}^{-1}$. Its $\mathrm{Cu}$ niche width extended from 201 up to $5194 \mathrm{mg} \mathrm{kg}^{-1} \mathrm{Cu}$, and had a skewed response with a tail toward the highest soil $\mathrm{Cu}$ concentrations (Fig. 1).

\section{Discussion}

In ex situ conditions, soil $\mathrm{Cu}$ concentrations did not significantly influence seedling emergence for any of the four plant species. It supports the observations of other studies on CRCO and DIMA in in vitro conditions showing that growing $\mathrm{Cu}$ concentration in substrate did not affect the percentage of germination (Boisson et al. 2016a; Boisson et al. 2016c). These results and those of other studies (Di Salvatore et al. 2008) suggest that the seed coat protects the plant embryo during the germination process from soil heavy metals.

Although no significant difference in seedling emergence rate of CRCO, GLLE and DIMA was found between populations, the outcome is consistent with previous studies on metallophytes populations of Spartina densiflora (Mateos-Naranjo et al. 2011) and Viola calaminaria (Bizoux et al. 2008). Only the seedling emergence of TRWE-RO was significantly affected by the interaction of the population's origin and the $\mathrm{Cu}$ concentration, suggesting ecotypic differentiation. While our study did not highlight this effect at the growth stage for tested species, the adaptation of metallophyte showing ecotypical differentiation has been already observed in Collinsia sparsiflora (Wright 
et al. 2006) or Helianthus exilis (Sambatti and Rice 2006) from serpentine soils. Large variation in biomass per plant were also shown for distinct populations of Noccea caerulescens (syn. Thlaspi caerulescens, Europa), Crepidorhopalon perennis (D.R. Congo) and Haumanisatrum katangense (D.R. Congo) cultivated on distinct metal concentrations (Roosens et al. 2003; Peng et al. 2012; Faucon et al. 2012a). The intraspecific variations correspond to a combination of environmentally-induced and genetic differences between populations (Mengoni et al. 2000; Van Rossum et al. 2004; Yang et al. 2005), implying an opportunity to choose appropriated ecotypes according to the purposes of the conservation strategies. The importance of the edaphic and the climatic tolerance is often neglected but some endemic species from the Katanga Copperbelt could benefit from a wide degree of tolerance presenting more optimized ecotypes for restoration strategies at mine closure or for phytostabilisation strategies of polluted soils (Boisson et al. 2015; Shutcha et al. 2015; Boisson et al. 2016b). Some more tolerant ecotypes of TRWE-RO may be more appropriate for restoration of soils with higher $\mathrm{Cu}$ concentrations and inversely, highlighting the importance of preserving a large variation of the ecotypes diversity.

Three different growth patterns in terms of increasing ex situ soil $\mathrm{Cu}$ concentration responses are represented by the four plant species including positive (CRCO), neutral (GLLE), and negative (DIMA; TRWE-RO). There was a positive correlation of plant size for CRCO to increasing soil $\mathrm{Cu}$ concentration with the largest individuals occurring in the $1000 \mathrm{mg} \mathrm{kg}^{-1} \mathrm{Cu}$ treatment soil, suggesting that this species requires high level of $\mathrm{Cu}$ for optimal development (Baker 1987). There was no correlation, however of soil $\mathrm{Cu}$ concentration with flower number in the species. Enhanced growth of some metallophytes in the presence of growing metal concentrations is rarely reported in plants. It was supposed on $H$. katangense and $C$. perennis (Chipeng et al. 2010; Faucon et al. 2012a), both occurring in the steppes of the $\mathrm{Cu}$ hills, as well as, other hyperaccumulators occurring on serpentine soils (Millie Burrell et al. 2012; Ghasemi et al. 2014). Enhanced plant growth in metal-polluted soil could be explained by plant growth promoting bacterias (PGPB) in the natural population (Khan 2005; Pereira et al. 2015). However, soils from natural sites (i.e., natural steppe) were not experienced in this study, excluding the hypothesis of PGPB. As well, mineral analysis of
CRCO plant after experiment showed that $\mathrm{Cu}$ concentrations in plant were constant whatever the $\mathrm{Cu}$ concentration in soil $\left(16.9 \pm 3.6 \mu \mathrm{g} \mathrm{g}^{-1} \mathrm{Cu}\right.$, unpublished data), suggesting that potential defense against biotic stresses or plant osmoregulation would not be greater at high metal concentrations (Whiting et al. 2003; Hörger et al. 2013). In most cases, these explanations are argued in case of hyperaccumulators (Noret et al. 2005; Fones et al. 2010; Krämer 2010). Because $\mathrm{Cu}$ acts as a fungicide, enhanced growth on $\mathrm{Cu}$-rich soil could result from a lower pathogen pressure than in normal soil, indicating a relaxed selection for resistance mechanisms (Chipeng et al. 2010; Faucon et al. 2012a). In contrast to CRCO's significant response to increasing soil $\mathrm{Cu}$ concentration, DIMA and TRWE-RO exhibited a significantly negative response. For DIMA and TRWE-RO, the largest individuals occurred in the lowest soil $\mathrm{Cu}$ treatment $\left(100 \mathrm{mg} \mathrm{kg}^{-1}\right)$ and the control. GLLE displayed an indifferent response to the range of soil $\mathrm{Cu}$ concentrations.

The patterns of response to soil $\mathrm{Cu}$ concentration by the four plant species generally reflect their patterns of distribution with respect to natural soil $\mathrm{Cu}$ concentration on the Cu hills (Parish and Bazzaz 1985; Eriksson 2002; Miriti 2006). CRCO exhibited positive growth response to increasing soil $\mathrm{Cu}$ concentration and displayed highest productivity at the highest soil $\mathrm{Cu}$ concentration. This species response supports the finding of $\mathrm{Cu}$ edaphic niche optimum at $10,139 \mathrm{mg} \mathrm{kg}^{-1} \mathrm{Cu}$, the highest of the four species. Conversely, DIMA and TRWE-RO shared the same pattern, with higher productivity in the lowest soil $\mathrm{Cu}$ treatment, since they had intermediate $\mathrm{Cu}$ niche widths between 0 and $6000 \mathrm{mg} \mathrm{kg}^{-1} \mathrm{Cu}$. Finally, GLLE had no significant response to soil $\mathrm{Cu}$ concentration in ex-situ conditions, exhibiting the broadest $\mathrm{Cu}$ edaphic niche with an optimum between DIMA and CRCO.

The indifferent response of GLLE to increasing soil $\mathrm{Cu}$ concentration, contrasting to its very high natural habitat soil $\mathrm{Cu}$ concentration (i.e., $\mathrm{Cu}$ edaphic niche), is best explained by the refuge endemism model (Gankin and Major 1964; Kruckeberg and Rabinowitz 1985). The refuge endemism model proposes that plant species with low interspecific competitive ability are competitively excluded from highly productive and competitive habitats in favor of stressful, lowly productive and competitive habitats to which they are tolerant, such as $\mathrm{Cu}$ hills. In the case of GLLE, in the absence of competition such as the ex situ study, the species performs equally well in very low to very high soil $\mathrm{Cu}$ concentration. 
Under natural habitat conditions however, the species most commonly occupies soils having the highest $\mathrm{Cu}$ concentration, possibly due to the effects of competitive exclusion from the lower and intermediate soil $\mathrm{Cu}$ concentrations. In contrast to GLLE, CRCO exhibits a strong positive response to increasing soil $\mathrm{Cu}$ concentration, best explained by the specialist endemism model (Boisson et al. 2016c).

Edaphic endemic specialist plant species are more competitive in their specialized habitat type than nonspecialists or tolerators (refuge endemics). The tolerance to the highest $\mathrm{Cu}$ concentrations usually comes at a physiological cost (Macnair 1993; Macnair et al. 2000; Chipeng et al. 2010; Faucon et al. 2012a) due to the presence of cellular mechanisms involved in $\mathrm{Cu}$ detoxification (Yruela 2005; Furini 2012). These strategies include the reduction of metal uptake, the stimulation of efflux, the chelation, the compartmentation and the sequestration (Yruela 2005). This strategy implies that individuals could show lower performances on nonmetal enriched soils than other species.

This study contributed to the quantification of the $\mathrm{Cu}$ edaphic niche of four endemic species, indicating that propagation conditions and the seed collection effort should depend on the species. Furthermore, it highlights that the restoration of $\mathrm{Cu}$ plant communities may be complex due to the various plant soil interaction within species level, as observed for TRWE-RO presenting various response to $\mathrm{Cu}$ concentrations according to the original population. The diversity of edaphic patterns observed for these species suggests that endemic species present opportunity for soil reclamation of degraded landscapes in south-eastern DRC. Notably, CRCO and GLLE could be used for the revegetation of highest $\mathrm{Cu}-$ rich soils while DIMA and TRWE-RO would be more adapted for intermediate $\mathrm{Cu}$-rich substrates.

\section{Conclusion}

In the conservation of strict edaphic endemic plant species, it is important to characterize their optimal habitat conditions. Quantified and well-understood niche parameters of a species increase the success of in situ population conservation, in situ habitat restoration, and ex situ propagation. Additional study of the numerous diverse $\mathrm{Cu}$ endemic plant species is needed to improve holistic conservation and restoration of the $\mathrm{Cu}$ hill ecosystems. These approaches would allow to determine the level of ecotypic and genetic variation within species, helping the choice of targeted site and the size of sampling. $\mathrm{Cu}$ and $\mathrm{Co}$ mining on the Katangan Copperbelt is a harsh disturbance that removes most of the local ecosystem function including organisms and soil, and causing a greater isolation than in the natural ecosystem. The barren, acidic heavy metal mine tailings represent an extreme habitat type to which the local $\mathrm{Cu}$ endemic plant species could be the most adapted for revegetation and reclamation purposes.

Acknowledgments This research study was made possible thanks to the financial intervention of the Fonds de la Recherche dans l'Industrie et dans l'Agriculture (FRIA) of the FNRS (Fonds National de la Recherche Scientifique), Belgium. FNRS. The Coopération Universitaire au Développement (CUD) is acknowledged for the funding support for the Faculty of Agronomy's seed bank at the University of Lubumbashi (PIC REMEDLU) and the fellowship of Olivier Garin who performed his Master's thesis in D.R. Congo. The authors also thank Tenke Fungurume Mining S.A.R.L (TFM, Freeport McMoran Copper \& Gold) for financial and logistic support in the field.

\section{References}

Aikaike H (1987) Factor analysis and AIC. Psychopharmacology 52:317-332

Anacker BL (2014) The nature of serpentine endemism. Am J Bot 101:219-224. doi:10.3732/ajb.1300349

Antonovics J, Bradshaw AD, Turner RG (1971) Heavy metal tolerance in plants. Adv Ecol Res 7:1-85

Baker AJM (1987) Metal Tolerance. New Phytol 106:93-111. doi:10.1111/j.1469-8137.1987.tb04685.x

Bizoux JP, Daïnou K, Raspé O, Lutts S, Mahy G (2008) Fitness and genetic variation of Viola calaminaria, an endemic metallophyte: implications of population structure and history. Plant Biol 10: 684-693. doi:10.1111/j.1438-8677.2008.00077.x

Boisson S, Collignon J, Langunu S, Lebrun J, Shutcha MN, Mahy G (2015) Concilier la phytostabilisation des sols pollués avec la conservation de la flore cupro-cobalticole dans la région de Lubumbashi (R.D. Congo) : une stratégie nouvelle pour valoriser les écosystèmes extrêmes. In: Bogart J, Halleux JM (eds) Territoires périurbains: Développement, enjeux et perspectives dans les pays du Sud. Presses Agronomiques de Gembloux, Gembloux, pp. 127-138

Boisson S, Ortmans W, Maréchal J, Majerus M, Mahy G, Arnaud $\mathrm{M}$ (2016a) No copper required for germination of an endangered endemic species from the Katangan Copperbelt (Katanga, DR Congo): Diplolophium marthozianum

Boisson S, Le Stradic S, Collignon J, Séleck M, Malaisse F, Ngoy Shutcha M, Faucon MP, Mahy G (2016b) Potential of copper-tolerant grasses to implement phytostabilisation strategies on polluted soils in south D. R. Congo: Poaceae candidates for phytostabilisation. Environ Sci Pollut Res 23: 13693-13705. doi:10.1007/s11356-015-5442-2 
Boisson S, Le Stradic S, Commans M, Dumont A, Leclerc N, Thomas C, Mahy G (2016c) Copper tolerance of three crotalaria species from southeastern D. R. Congo at the early development stage. Biotechnol Agron Soc Environ 20:151160

Boyd RS (2007) The defense hypothesis of elemental hyperaccumulation: status, challenges and new directions. Plant Soil 293:153-176. doi:10.1007/s11104-007-9240-6

Boyd R, Rajakaruna N (2013) Heavy metal tolerance. In: Gibson D (ed) Oxford bibliographies in ecology. Oxford University Press, New York, pp. 1-24

Brooks R (1998) Plants that hyperaccumulate heavy metals. CAB International, Wallingford, UK

Brooks RR, Malaisse F (1990) Metal-enriched sites in south central africa. In: Shaw J (ed) Heavy metal tolerance in plants: evolutionary aspects. CRC Press, Inc, New York, pp. 53-71

Cailteux JLH, Kampunzu AB, Lerouge C, Kaputo AK, Milesi JP (2005) Genesis of sediment-hosted stratiform copper-cobalt deposits, central African Copperbelt. J African Earth Sci 42: 134-158. doi:10.1016/j.jafrearsci.2005.08.001

Chipeng FK, Hermans C, Colinet G, Faucon M-P, Ngongo M, Meerts P, Verbruggen N (2010) Copper tolerance in the cuprophyte Haumaniastrum katangense (S. Moore) P.A. Duvign. \& Plancke. Plant Soil 328:235-244. doi:10.1007 /s11104-009-0105-z

Di Salvatore M, Carafa AM, Carratù G (2008) Assessment of heavy metals phytotoxicity using seed germination and root elongation tests: A comparison of two growth substrates. Chemosphere 73(9):1461-1464

Duvigneaud P, Denaeyer-De Smet S (1963) Etudes sur la végétation du Katanga et de ses sols métallifères. Communication $\mathrm{n}^{\circ} 7$ Cuivre et végétation au Katanga. Bull la Société R Bot Belgique 96:93-231

Eriksson O (2002) Ontogenetic niche shifts and their implications for recruitment in three clonal Vaccinium shrubs: Vaccinium myrtillus, Vaccinium vitis-idaea, and Vaccinium oxycoccos. Can J Bot 80:635-641. doi:10.1139/B02-044

Escarré J, Lefèbvre C, Frérot H, Mahieu S, Noret N (2013) Metal concentration and metal mass of metallicolous, non metallicolous and serpentine Noccaea Caerulescens populations, cultivated in different growth media. Plant Soil 370: 197-221. doi:10.1007/s11104-013-1618-Z

Faucon M-P, Meersseman A, Shutcha MN, Mahy G, Luhembwe MN, Malaisse F, Meerts P (2010) Copper endemism in the Congolese flora: a database of copper affinity and conservational value of cuprophytes. Plant Ecol Evol 143:5-18. doi:10.5091/plecevo.2010.411

Faucon M-P, Parmentier I, Colinet G, Mahy G, Ngongo Luhembwe M, Meerts P (2011) May rare metallophytes benefit from disturbed soils following mining activity? The case of the Crepidorhopalon tenuis in Katanga (D. R. Congo). Restor Ecol 19:333-343. doi:10.1111/j.1526-100 X.2009.00585.x

Faucon M-P, Chipeng F, Verbruggen N, Mahy G, Colinet G, Shutcha M, Pourret O, Meerts P (2012a) Copper tolerance and accumulation in two cuprophytes of south Central Africa: Crepidorhopalon perennis and C. tenuis (Linderniaceae). Environ Exp Bot 84:11-16. doi:10.1016/j. envexpbot.2012.04.012
Faucon M-P, Tshilong BM, Van RF, Meerts P, Decocq G, Mahy G (2012b) Ecology and hybridization potential of two sympatric metallophytes, the narrow endemic Crepidorhopalon perennis ( Linderniaceae ) and its more widespread congener. Biotropica 44:454-462

Faucon MP, Le Stradic S, Boisson S, EI w I, Séleck M, Lange B, Guillaume D, MN S, Pourret O, Meerts P, Mahy G (2016) Implication of plant-soil relationships for conservation and restoration of copper-cobalt ecosystems. Plant Soil 403:153-165. doi:10.1007/s11104015-2745-5

Fones H, Davis C a R, Rico A, Fang F, Smith JAC, Preston GM (2010) Metal hyperaccumulation armors plants against disease. PLoS Pathog 6:1-13. doi:10.1371/journal. ppat.1001093

François A (1973) L'extrémité occidentale de l'Arc Cuprifère Shabien. Etude géologique-Département de géologie de la Gécamines, Likasi (République du Zaire)

Furini A (ed) (2012) Plants and heavy metals. Springer Netherlands, Dordrecht

Gankin R, Major J (1964) Arctostaphylos myrtifolia, its biology and relationship to the problem of endemism. Ecotoxicology 45:792-808

Gégout J-C, Pierrat J-C (1998) L'autécologie des espèces végétales : Une approche par régression non paramétrique. Ecotoxicology 29:473-482

Ghasemi R, Chavoshi ZZ, Boyd RS, Rajakaruna N (2014) A preliminary study of the role of nickel in enhancing $\mathrm{fl}$ owering of the nickel hyperaccumulating plant Alyssum inflatum Nyár. (Brassicaceae). South African J Bot 92:4752. doi:10.1016/j.sajb.2014.01.015

Godefroid S, Van de VA, Massengo Kalenga W, Handjila Minengo G, Rose C, Ngongo Luhembwe M, Vanderborght T, Mahy G (2013) Germination capacity and seed storage behaviour of threatened metallophytes from the Katanga copper belt (DR Congo): implications for ex situ conservation. Plant Ecol Evol 146:183-192. doi:10.5091/plecevo.2013.745

Harrison SP, Rajakaruna N (2011) Serpentine: the evolution and ecology of a model system. University of California Press, Berkeley

Hastie T, Tibshirani R (1986) Generalized additive models. Stat Sci 1:297-318

Hörger AC, Fones HN, Preston GM (2013) The current status of the elemental defense hypothesis in relation to pathogens. Front Plant Sci 4:395. doi:10.3389 /fpls.2013.00395

Ilunga wa Ilunga E, Séleck M, Colinet G, Meerts P, Mahy G (2013) Small-scale diversity of plant communities and distribution of species niches on a copper rock outcrop in upper Katanga, DR Congo. Plant Ecol Evol 146:173-182. doi:10.5091/plecevo.2013.816

Khan AG (2005) Role of soil microbes in the rhizospheres of plants growing on trace metal contaminated soils in phytoremediation. J Trace Elem Med Biol 18:355-364. doi:10.1016/j.jtemb.2005.02.006

Krämer U (2010) Metal hyperaccumulation in plants. Annu Rev Plant Biol 61:517-534. doi:10.1146/annurev-arplant042809-112156 
Kruckeberg AR (1986) An essay: the stimulus of unusual geologies for plant speciation. Syst Bot 11:455. doi:10.2307 $/ 2419082$

Kruckeberg AR, Kruckeberg A (1990) Endemic metallophytes: their taxonomic, genetic and evolutionary attributes. In: Shaw J (ed) Heavy metal tolerance in plants: evolutionary aspects. CRC Press Inc, New York, pp. 301-312

Kruckeberg AR, Rabinowitz D (1985) Biological aspects of endemism in higher plants. Annu Rev Ecol Syst 16:447-479. doi:10.1146/annurev.es.16.110185.002311

Lakanen E, Erviö R (1971) A comparison of eight extractants for the determination of plant available micronutrients in soil. Acta Agral Fenn 123:223-232

Leteinturier B (2002) Evaluation du potential phytocénotique des gisements cupriferes d'Afrique centro-australe en vue de la phytoremédiation de sites pollués par l'activité. PHD Thesis. p 358

Leteinturier B, Baker AJM, Malaisse F (1999) Early stages of natural revegetation of metalliferous mine workings in south Central Africa: a preliminary survey. Biotechnol Agron Soc Environ 3:28-41

Macnair MR (1993) The genetics of metal tolerance in vascular plants. New Phytol 124:541-559. doi:10.1111/j.14698137.1993.tb03846.x

Macnair M, Gardner M (1998) The evolution of edaphic endemics. In: Howard D, Berlocher S (eds) Endless Forms. Species and Speciation. Oxford University Press, New York, pp. 157-171

Macnair M, Tilstone G, Smith S (2000) The genetics of metal tolerance and accumulation in higher plants. In: Terry N (ed) phytoremediation of contaminated soil and water. CRC Press Inc, p. 408

Malaisse F, Baker AJM, Ruelle S (1999) Diversity of plant communities and leaf heavy metal content at Luiswishi copper/ cobalt mineralization, upper Katanga, Dem. Rep. Congo. Biotechnol Agron Soc Environ 3:104-114

Margesin R, Schinner F (2005) Manual for soil analysis - monitoring and assessing soil bioremediation: monitoring and assessing soil bioremediation. Springer

Mateos-Naranjo E, Andrades-Moreno L, Redondo-Gómez S (2011) Comparison of germination, growth, photosynthetic responses and metal uptake between three populations of Spartina densiflora under different soil pollution conditions. Ecotoxicol Environ Saf 74:2040-2049. doi:10.1016/j. ecoenv.2011.06.019

Mengoni A, Gonnelli C, Galardi F, Gabbrielli R, Bazzicalupo M (2000) Genetic diversity and heavy metal tolerance in populations of Silene paradoxa L. (Caryophyllaceae): a random amplified polymorphic DNA analysis. Mol Ecol 9:13191324

Meyer S (1986) The ecology of gypsophile endemism in the eastern Mojave Desert. Ecotoxicology 67:1303-1313

Millie Burrell A, Hawkins AK, Pepper AE (2012) Genetic analyses of nickel tolerance in a north American serpentine endemic plant, Caulanthus amplexicaulis var. barbarae (Brassicaceae). Am J Bot 99:1875-1883. doi:10.3732 /ajb.1200382

Miriti MN (2006) Ontogenetic shift from facilitation to competition in a desert shrub. J Ecol 94:973-979. doi:10.1111 j.1365-2745.2006.01138.x
Mukalay MJ, Shutcha NM, Tshomba KJ, Mulowayi KA, Kamb CF, Ngongo Luhembwe M (2008) Causes d'une forte hétérogénéité des plants dans un champ de maïs dans les conditions pédoclimatique de Lubumbashi. Ann la Fac des Sci Agron 1:4-11

Noret N, Meerts P, Tolrà R, Poschenrieder C, Barceló J, Escarre J (2005) Palatability of Thlaspi Caerulescens for snails: influence of zinc and glucosinolates. New Phytol 165:763-771. doi:10.1111/j.14698137.2004.01286.x

Parish J, Bazzaz F (1985) Ontogenetic niche shifts in old-field annuals. Ecotoxicology 66:1296-1302

Peng H, Wang-Müller Q, Witt T, Malaisse F, Küpper H (2012) Differences in copper accumulation and copper stress between eight populations of Haumaniastrum katangense. Environ Exp Bot 79:58-65. doi:10.1016/j. envexpbot.2011.12.015

Pereira SIA, Barbosa L, Castro PML (2015) Rhizobacteria isolated from a metal-polluted area enhance plant growth in zinc and cadmium-contaminated soil. Int J Environ Sci Technol 12: 2127-2142. doi:10.1007/s13762-014-0614-Z

R Development Core Team (2010) A language and environment for statistical computing. Vienna (Austria)

Rajakaruna N (2004) The edaphic factor in the origin of species. Int Geol Rev 46:471-478

Rajakaruna N, Boyd RS (2008) The edaphic factor. In: Jorgensen SE, Fath B (eds) The encyclopedia of ecology, Elsevier, vol 2. Oxford, United Kingdom, pp. 1201-1207

Roosens N, Verbruggen N, Meerts P, Ximénez-Embun P, Smith JAC (2003) Natural variation in cadmium tolerance and its relationship to metal hyperaccumulation for seven populations of Thlaspi caerulescens from western Europe. Plant, Cell Environ 26:1657-1672

Saad L, Parmentier I, Colinet G, Malaisse F, Faucon M-P, Meerts P, Mahy G (2012) Investigating the vegetation-soil relationships on the copper-cobalt rock outcrops of Katanga (D. R. Congo), an essential step in a biodiversity conservation plan. Restor Ecol 20:405-415. doi:10.1111/j.1526-100 X.2011.00786.x

Sambatti JBM, Rice KJ (2006) Local adaptation, patterns of selection, and gene flow in the Californian serpentine sunflower (Helianthus exilis). Evolution (N Y) 60:696710. doi:10.1111/j.0014-3820.2006.tb01149.x

Séleck M, Bizoux J-P, Colinet G, Faucon M-P, Guillaume A, Meerts P, Piqueray J, Mahy G (2013) Chemical soil factors influencing plant assemblages along coppercobalt gradients: implications for conservation and restoration. Plant Soil 373:455-469. doi:10.1007/s11104013-1819-5

Shaw J (1990) Heavy metal tolerance in plants: evolutionary aspects. CRC Press Inc, New York

Shutcha MN, Faucon M-P, Kamengwa Kissi C, Colinet G, Mahy G, Ngongo Luhembwe M, Visser M, Meerts P (2015) Three years of phytostabilisation experiment of bare acidic soil extremely contaminated by copper smelting using plant biodiversity of metal-rich soils in tropical Africa (Katanga, DR Congo). Ecol Eng 82:81-90. doi:10.1016/j. ecoleng.2015.04.062

Springer YP (2009) Do extreme environments provide a refuge from pathogens? A phylogenetic test using serpentine flax. Am J Bot 96:2010-2021. doi:10.3732/ajb.0900047 
Strauss SY, Boyd RS (2011) Herbivory and other cross-kingdom interactions on harsh soils. In: Rajakaruna N (ed) Harrison SP. University of California Press, SerpentineThe Evolution and Ecology of a Model System, pp. 180-199

Van Rossum F, Bonnin I, Fenart S, Pauwels M, Petit D, Saumitou-Laprade P (2004) Spatial genetic structure within a metallicolous population of Arabidopsis halleri, a clonal, self-incompatible and heavy-metal-tolerant species. Mol Ecol 13:2959-2967. doi:10.1111/j.1365-294 X.2004.02314.X

Whiting SN, Neumann PM, Baker AJM (2003) Nickel and zinc hyperaccumulation by Alyssum murale and Thlaspi Caerulescens (Brassicaceae) do not enhance survival and whole-plant growth under drought stress. Plant, Cell Environ 26:351-360. doi:10.1046/j.13653040.2003.00959.x

Wright JW, Stanton ML, Scherson R (2006) Local adaptation to serpentine and non-serpentine soils in Collinsia sparsiflora. Evol Ecol Res 8:1-21

Yang XE, Jin XF, Feng Y, Islam E (2005) Molecular mechanisms and genetic basis of heavy metal tolerance/ hyperaccumulation in plants. J Integr Plant Biol 47:10251035. doi:10.1111/j.1744-7909.2005.00144.x

Yruela I (2005) Copper in plants. Brazilian J Plant Physiol 17: $145-156$ 